\title{
SOME DIFFERENCES BETWEEN BOCCACCIO'S AND CHAUCER'S TALES OF GRISELDA
}

\author{
Brunilda Reichmann Lemos \\ Universidade Federal do Paraná
}

\section{SUMMARY}

This paper tries to demonstrate that Chaucer in his "Tale of Griselde" has used, besides Boccaccio's tale, Petrarch's revised verson, as it is found in the Epistolae seniles, Manuseript 1165, and Mézière's translation as it appears in Le Ménagier de Paris.

Since the end of the 19th century, critics have been trying to establish relationships between Chaucer's "The "Clerk's Tale" and other verstons of the same story in Italian, Latin, and French. If we ignore the Italian versions in existence before Chaucer's writing of the story of Griselda, we still have to deal with more than thirty versions in Latin and French. Severs ${ }^{1}$ presents a list of iwenty-fou, manuscripts in Latin and seven in French, all existing before Chaucer's "The Clerk's Tale."

Critics have, monetheless, before the publication of Sourees and Analogues of Chaucer's Canterbury Tales in 1958, ${ }^{2}$ sorted out some manuscripts or versions as being those which Chaucer most probably knew and used. They were the Basle manuscript and Manuscript $1165^{3}$, the French translation by Philippe de Mézieère 4 published in Le Ménagier de Paris, and Boccaccio's version ${ }^{3}$ which was the first literary rendering of the tale of Griselda. In the middle of the 20th certury, with the publication of Sources and Analogues of Chaucer's Cantebury Tale, Severs refutes some similarities between Chaucer's tale and the Basle manuscript, ${ }^{6}$ the French translation by Mézière, and Boccaccio's tale. Severs affirms that Chaucer's only sources were Petrarch's version of the tale, as it appears in Epistolae seniles, and the French version wich he calls Manuscript 1165.

1 SEvfrs, J. Rurke. The Clerk's Trle. In: BRTAN, W. F, DEMPSTFR, G., ed. Sources and Analogues of Chaucer's Canterbary Tales. New York. Iumanitles Press, 1958. D. 292-4.

2 SEVERS, J. Burke. Chaucer's Source MSS. for the Clorken Tale. Pablleation of the Modern Language Aggociation, 37:431-52, 1932. COOK, A. S. Chaucer's Clerk's Tale anda a French Version oh His Orininal. Rnmanle Review, 37:210-22, 1917. FAR. NHAM, W. F. Chnucer's Clerk's Tale. Modern Ianeuage Notek, $33: 193-203,1918$.

3 SEVERS, Chaucer's Source..., p. 431-52.

4 COOK. D. 210-22.

3 FARNHAM, p. 193-203.

e Notlee that in his article published in PMLA in 1932 he considers the Banle manuseript as one of Chaucer's sources. 
Since neither we nor the critics can ever prove which versions of the tale of Griselda Chaucer knew, let us suppose that the knew also Boccaccio's, besides Petrach's and the anonymus French version of the same tale (Manuscript 1165). We will see later, however, that Chaucer probably also used or knew Mézière's.

If we make a list of the similarities between Chaucer's "The Clerk's Tale" and those other four versions, we will probably notice an interesting 'fact concerning Boccaccio's influence upon Chaucer. While the similarities between the other three versions (Petrarch's, Mézière's, and Manuscript 1165) and Chaucer's are found scattered all through Chaucer's versions, similarities between Boccaccio's and Chaucer's tales are found only in the second half of the English version. ${ }^{7}$ It seems quite evident that Chaucer came in contact with Boccaccio's tale in the middle of writing his own. But even though Chaucer may not have known Boccaccio's tale before starting to write his own, if we compare Boccaccio's and Chaucer's tales, the differences found between the two versions may lead us to the other sources used by Chaucer.

This essay will touch on some details which are arranged differently in Boccaccio's and Chaucer's tales, and on other details which are nonexistent in Boccaccio but can be found in Petrarch's version, Manuscript 1165 or in the French translation by Mézière.

The first noticeable difference in the arrangement of details occurs in the marquis' talk to Janicula about his intentions of marrying Griselda. In Boccaccio, the marquis (Gualtieri) sends for Grannucole as soon as he decides to marry.

E per cid, sensa più avanti cercare, costei propose di volere sposare: e fattosi il padre chiamare, con lui che poverissimo era, si convenne di torla per moglie. ${ }^{8}$

Therefore, when the marriage day comes, Gualtieri only reminds Giannucole that he came to marry Griselda. It is implied that Giannucole agreed upon the marriage

Allora Gualtieri smontato e comandato ad ogn'vomo che I'aspettasse, solo se n'entrò nella povera casa, dove trovo il padre di lei che aveva nome Giannucole, e dissegli: "lo son venuto a sposar la Griselda, ma prima da lei voglio sapere alcuna cosa in tua presenzia". 9

According to Farnhnm's analysis of the similarities between Chaucer's and Bocenccio's tale.

Boccaccio, Giovanni. Decameron. Firenze, Le Monnier, 1952. v. z, p. 646.

9 BOCCACCIO, p. $647,648$. 
In Chaucer, on the other hand, Janicula knows as little as Griselde about the marquis' wishes to marry her. When the appointed day for the marriage comes, Walter rides to Griselde's house and says

"Where is youre fader, O Grisldis?" he sayde.

And she with reverence, in humble cheere,

Answerde, "Lord, he is al redy heere."

And in she gooth withouten lenger lette,

And to the markys she hir fader fette.

He by the hand thanne took this olde man,

And seyde thus, whan he hym hadde asyde:

"Janicula, I neither may ne kan

Lenger the plesance of myn herte hyde.

Is that thou vouche sauf, wath so bityde;

Thy doghter wol I take, er that I wende, As for my wyf, unto hir lyves ende.

"Thou lovest me, I woot it wel certeyn,

And art my feithful lige man ybore;

And al that liketh me, 1 dar wel seyn

It liketh thee, and specially therfore

Tel me that poynt that I have seyd bifore,

If that thou wolt unto that purpos drawe,

To take me as for thy sone-in-lawe." 10

Chaucer is here following Petrachs's version and Manuscript 1165. He enchances, by presenting a dramatic encounter between Walter and Janicula, the emotional intensity of the characters and of the tale.

In Petrarch we have:

Tun Valterius, cogitabundus incedens eamque compellans nomine, ubinam pater eius esset interrogativ; que cum illum domi esse reverenter atque humiliter respondisset, "lube," inquit, "ad me veniat." Venientem seniculum, manu prehensum, parumper abstraxit ac submissa voce, "Scio," ait, "me, lanicola, carum tibi, teque hominem fidum novi, et quecumque mich placeant vele te arbitror. Unum tamen nominatim nosse velim: an me, quem dominum habes, dat amich hac tua in uxorem filia, generum velis?" 11

10 ROBINSON. F. N., ed. The Works of Geoffrey Chaucer. 2. ed. Boston, H. Mifflin. 1957. p. 104.

11 SEVERS, Sources and Analogaes..., p. 304. 


\section{And in Manuscript 1165}

Et tout ainsy qu'elle vouloit entrer en leur maison, le marquis, tout pensis, vient au devant d'elle, en lui demandat ou estoit son pere; daquelle lu respondi humblement et en tres grant reverence: "Monseigneur," dist elle, "en nostre hostel."

"Ou lu dis," fait il, "qu'il viengne parler a moy." Et quant ce bon homs fut venus, il le prist par la mai $n$ et le tira a part et en basse voix lui dist: "Je scay," dist il, "Janicole, que tu m'ainmes et as bien chier, et es mon homme feable, et que quelconques choses me plaisent, tu les veulz et te plaisent. Une chose toutesfoiz especiaulment vueil savoir: se il te plaist bien que j'aye ceste tienne fille a femme et me vueille avoir ton gendre." 19

Chaucer's second departure from Boccaccio gives the English version of the tale a touch of delicary not found in the Italian. In both versions, the Italian and the English, the marquis is gentle enough to ask for Griselda's acceptance of the marriage before he presents her to those nobles who accompanied him, as his wife. He could have merely taken Griselda without asking her since he was a lord and she was peasant. But in Boccaccio, he has Griselda stripped naked in front of all the nobles and dressed in royal garments before he asks her if she consents to be his wife.

Allora Gualtieri, presala per mano, la menò fuori, e in presenzia di tutta la sua compagnia e d'ogni altra persona la fece spogliare ignuda, e fattisi guegli vestimenti venire che fatti aveva fare, prestamente la fece vestire e calzare, e sopra i suoi capegli cosi scarmigliati com'erano le fece mettere una corona; e appresso questo, maravigliandosi ogn'vomo di questa cosa, disse: "Signori, costei è colei la quale io intendo che mia moglie sia, dove ela me voglia per marito", e poi a lei rivolto, che di se medesima vergognosa e sospesa stava, le disse: "Griselda, vuo'mi iu per tuo marito?"

A cui ella rispose: "Signor mio, si". ${ }^{18}$

In Chaucer, on the other hand, it is implied that Griselda accepts 
Wolter's offer before the marquis orders the ladies to change her clothes. As soon as Griselde agrees upon being his wife, Walter presents her to his company, in her rags, as his future wife. Chaucer is also silent about her clothes being changed in public.

"Wondrynge upon this word, quakynge for drede, She seyde, "Lord, undigne and unworthy Am I to thilke honour that ye me beede, But as ye wole youreself, right so woll. And heere I swere that nevere willyngly, In werk ne thoght, I nyl yow disobeye, For to be deed, though me were looth to deye."

"This is ynogh, Grisilde myn," quod he.

And forth he gooth, with a ful sobre cheere, Out at the dore, and after that cam she, And to the peple he seyde in this manere: "This is my wyf," quod he, "that standeth heere, Honoureth hire and loveth hire, I preye, Whoso me loveth; ther is namoore to seye."

And for that no thyng of hir olde geere

She sholde brynge into his hous, he bad That wommen sholde dispoillen hire right theere; Of wich thise ladyes were nat right glad To handle hir clothes, wherinne she was clad. But nathelees, this mayde bright of hewe Fro foot to heed they clothed han al newe.' 14

Again Chaucer is following the Latin version and Manuscript 1165 closely. In Latin, Petrarch writes:

Ad hec illa miraculo rei tremens, "Ego, mi domine," inquid, "tanto honore me indignam sclo; at si voluntas tua, sique sors mea est, nichil ego unquam sciens, nedum faciam, sed efiam cogitabo, quod contra animum tuum sit; nec tu aliquid facies, etsi me mori iusseris, quod moleste feram." "Satis est," inquit ille; sic in publicum eductam populo ostendens, "Hec," ait, "uxor mea, hec domina vestra est; hanc colite, hanc amate, af si me carum habteis, han ccarissimam habetote." Hne ne quid reliquiarum fortune veteris novam inferret in domum, 
nudari eam iussit, et a calce ad verticem novis vestibus indui, quod a matronis circumstantibus ac certatim sinu illam gremioque foventibus verecunde ac celeriter adimpletum est. ${ }^{15}$

And in French:

A ces choses, de ce fait merveilleux toute tremblant, respondi: "Je," dist elle, "monseigneur, sçay certainement que je ne suis pas digne ne souffisant de si grant honneur. Et se ceste chose toutesfois est ta voulenté et mon eur, jamais riens ne feray ne penseray quelque chose a mon povoir qui soit contre ta voulenté ou plaisir, ne tu ne feras ja chose, et me feisse mourir, que je ne seuffre pacienment."

"C'est assez," distil; et ainsy la fist amener devant tous en publique et dist au peuple: "Ceste," fait il, "ma meffe et vostre dame est. Honnorez la, amez la. Et se vous m'avez chier, je vous prie, aiez la tres chiere." Et incontinenti la commanda a devestir toute nue et du pie jusques au chief la fist revestir de neuves robes tres richement par les bonnes dames qui la estoient. Laquelle chose firent moult honteusement pour le regart des vilz ef povres vestemens qu'elles lui desvestoient aux precieuses que on lui vestoit. ${ }^{16}$

Chaucer's third and fourth departures from Boccaccio seem to be creations of the English poet for enhancing the intensity of amotion in Griselde's character. They are Griselde's plea to the sergeant to allow her to say good-bye to her daughter and her stanza-long farewell to the baby.

But atte laste to speken she bigan, And mekely she to the sergeant preyde, So as he was a worthy gentil man, That she moste kisse hire child er that it deyde. And in hir barm this litel child she leyde With ful sad face, and gan the child to blisse, And lulled it, and after gan it kisse.

And thus she seyde in hire benigne voys, "Fareweel my child! I shal thee nevere see. But sith I thee have marked with the croys 
Of thilke Fader - blessed moote he bel -

That for us deyde upon a croys of tree,

Thy soule, litel child, I hym bitake,

For this nyght shaltow dyen for my sake." 17

Several time in "The Clerk's Tale" Chaucer elaborates, as he does here, upon the characters found in Boccaccio, Petrarch, and Manuscript 1165. All of Chaucer's expansions and additions deepen and individualize the characterization of the protagonists.

Chaucer also places special emphasis upon the repeated pattern in the story (the trials and Griselde's success in them) by having the marquis remind her, before each trial, of her duty and promise to him. In Boccaccio this pattern is not emphasized as in Chaucer, even though Griselda goes through the same trials. For example, when the marquis tells Griselda that her baby boy will have the same destiny the first one had, he also mentions that he might marry another woman. Gualtieri says

Donna, poscia che tu questo figliuol maschio facesti, per niuna guisa con questi miei viver son potuto, sì duramente si ramaricano che uno nepote di Giannucolo Jopo me debba rimaner lor signore: di che io $\mathrm{mi}$ dotto, se io non ci vorrò esser cacciato, che non mi convenga far di quello che io altra volta feci, e alla fine lasciar te $e$ prende un'altra moglie. ${ }^{18}$

Chaucer, on the other hand, is following Petrarch and Manuscript 1165 again when he presentes each trial separately and elaborates on the material between the second and third trials.

By the same token, Chaucer introduces the sergeant the second lime, as in the Latin and French versions. Boccaccio does not even mention the sergeant again.

Dopo non molti di Gualtieri, in quella medesimo maniera che mandato avea per la figlivola, mandó per lo figluiolo, e similmente dimostrato d'averlo fatto uccidere, a nutricar nel mandò a Bologna, come la fanciulla aveva mandata. ${ }^{10}$

Chaucer, like Petrarch and Manuscript 1165, introduces the sergeant again. The character is silent this time; only his brutal action

17 ROBINSON, p. 107.

18 BOCCACCIO, p. 651 .

18 BOCCACCIO, p. $651,652$. 
is mentioned since it is the important point in the recurrence of the trial. Griselde again asks for the same favor she had requested before.

This ugly sergeant, in the same wyse That he hire doghter caughte, right so he, Or worse, if men worse kan devyse, Hath hent hire sone, that ful was of beautee.

And evere in oon so pacient was she That she no chiere maade of hevynesse, But kiste hir sone, and after gan it blesse;

Save this, she preyede hym that, if he mygthe,

Hir litel sone he wolde in erthe grave,

His tendre lymes, delicaat to sighte,

Fro foweles and fro beestes for to save.

But she noon answere of hym myghte have.

He wente his wey, as hym no thyng ne roghte;

But to Boloigne he tendrely ih grobhte. ${ }^{20}$

In Petrarch:

Illa eodem quo semper vultu, qualicunque animo, filium forma corporis atque indole non matri tantum sed cunctis amabilem in manus cepit, signansque eum signo crucis et benedicens ut filiam fecerat, et diuticule oculis inherens, atque deosculans, nullo penitus signo doloris edito, petenti obtulit. "Et tene," inquid, "fac quod iussus es. Unum nunc etiam precor: ut, si fieri potest, hos artus teneros infantis egregij protegas a vexatione volucrum ac ferarum." 21

And in Manuscript 1165:

Lequel sergent, en soy excusant comment il lui convenoit obeir, ainsi comme se il voulsist faire une grande inhumanite, demanda l'enfant comme il avoit fait l'autre, et elle respondy de bonne chiere, ja fust ce que bien estoit courroucee en cuer. Son filz moult bel et doulcet prist entre ses bras ef le beneist ef seigna, comme elle avoit fait le fille, et un petit longuement le regarda et le baisa, sans monstrer signe de douleur, et au messaige le bailla. "Tien," dist elle, "fay ce a quoy tu es envoié. 
Une chose, toutesfoiz, te requier chierement tant que je puis: que, se tu pues faire, tu vueilles garder et deffendre le corps et membres de ce noble enffant, que bestes mauvaises ne le devourent ou menguent." 22

The last detail to be discussed here shows Chaucer's use or knowledge of other versions of the story besides Petrarch's and Manuscript 1165. Cook, who analyzes the similarities between Chaucer's tale and Mézière's French translation, published in Le Ménagier de Paris, says:

Chaucer twice speaks of Griselda as falling to the ground in a swoon, once [whan she this herde, aswowne doun she falleth / For pitous joye (1079-90)] after Walter acknowledges his children, and again--[Al sodeynly she swapte adoun to grounde (1099)] after she has tenderly embraced and addressed them. Petrarch knows nothing of an actual swoon, but merely declares that she was nearly dead with joy, and mad with affection (pene gaudio exanimis ef pietate amens), while the Menagier (1. 123) tells of one swoon: "Oyant les paroles de son mary cheist devant lui tout pasmee a terre." ${ }^{23}$

Cook finds forty-eight other similarities between Chavcer's "The Clerk's Tale" and Mézière translation as it is published in Ls Ménagier de Paris. But although several of the similarities pointed out by Cook seem valid, many are also found in Petrarch and Manuselipt 1165; others are similar only in wording which could have been mere coincidence; and still othe"s are questioned by Severs in his article "Chaucer's Source MSS for the Clerk's Tale."

The few details presented in this essay show, nonetheless, that although Chaucer may have used Boccaccio's tale of Griselda as a source for his own (as Farnham points out), Chaucer has undoubtedly known or even read at least three other versions: Petrarch's revised version, as it is found in the Epistole seniles, Manuscript 1165, and Mézière's translation as it appears in Le Ménagier de Paris. 


\section{R E S U M O}

Este trabalho procura demonstrar que Chaucer, ao contrário da op̣iniāo crítice. Usou $\mathrm{sm}$ sua "Tale of Griselde" não apenas a versão cie Boccaccio mas também a versão de Petrarca, do Manuscrito 1165 e a tradução de Mézière como aparece em Le Ménagier de Paris.

\section{BIBLIOGRAPHY}

1 BOCCACCIO, Giovanni. Decameron. Firenze, Le Monnier, 1952. v. 2.

2 CATE. W. A. The Problem of the Origin of the Griselda Story. Studies in Philology, 29:289-405, 1932

3 COOK. A. S. Chaucer's Clark's Tale and a French Version of His Original. Romanic Review, 7:210-22, 1917.

$\triangle$ FARNHAM, W. E. Chaucer's Clerk's Tale. Modern Language Notes, 33:193-203, 1918.

5 FRENCH. R. D. A Chaucer Handbook. 2. ed. New York. Appleton-Century-Crofts, 1947.

5 GRIFFITH, D. D. The Origin of the Griselda Story. Seattle, University of Washington, 1931.

7 HENDRICKSON. G. L. Chaucer and Petrarch: Two Notes on the 'Clerk's Tale'. iviodern Philology, 4:179-92, 1906/07.

2 JUSSERAND. J. J. Did Chaucer Meet Petrarch? Nineteenth Century, 39:993-1005. Jan./Jun. 18S6.

9 MATHER, F. J. On the Asserted Meeting of Chaucer and Petrarch. Modern Language Notes, 12:1-18, 1897.

10 ROBINSON. F. N.. ed. The Works of Geoffrey Chaucer. 2. ed. Boston, H. Miffin, 1957.

11 SEVERS, J B. Chaucer's Source MSS. for the Clerkes Tale. Publication of the Modern Language Association, 47:431-52, 1932.

is - The Clerk's Tala. In: BR!AN, W. F. \& DEMPSTEF. G. ed. Scurces and Analogues of Chaucer's Canterbury Tales. New York, Humanities Press, 1958. p. 288-331. 